\title{
An Investigation into the Effectiveness of the English as a Foreign Language Course
}

\author{
Le Van Tuyen \\ Ho Chi Minh City University of Technology (HUTECH), Ho Chi Minh City-Vietnam
}

\begin{abstract}
The current study was conducted with the aim of investigating the effectiveness of the B1 EFL course at a university in Ho Chi Minh City, Vietnam through teachers' and students' (postgraduates) perceptions about language needs analysis, objective identification, time allocation, content and materials, and testing. A self-structured questionnaire and the Group interview were employed with participation of 53 students and 4 teachers who implemented the course. The findings of the study have revealed that weaknesses still exist in the implementation of the course and that the students were not very satisfied with their learning outcomes; and recommendations for improvement of the implementation of the EFL course are provided. The study is significant for its empirical data collected from the Vietnamese context. Through this study, teachers and students of English have raised their opinions about the current situation of English education at the university in particular and in Vietnam in general.
\end{abstract}

Keywords: B1 EFL course, EFL teachers, students, perceptions, effectiveness

\section{INTRODUCTION}

Although English as a foreign language (EFL) made its presence in Vietnam at least before 1954, not until 1986 has it grown rapidly and expanded widely in Vietnam. One of the major reasons is that the Government of Vietnam does not want to lag behind in comparison with regional countries as well as other countries in the world, so since 1986, it has created initiatives to boost its economy. One of the strategic goals for developing economy is the critical role of EFL in Vietnam's education system. That is why the government is determined to improve its entire population's English proficiency in order to elevate national competitiveness. Accordingly, English must be taught at almost all levels of the national education system from secondary schools to higher educational institutions, and it is expected that in 2019 English will be taught at primary level from grade 3 to grade 5 in the whole country (MoET, 2008).

In Vietnam, English is not the medium of instruction in the school system. It only has the status of a major foreign language which is a compulsory subject at secondary school education, and for undergraduates and postgraduates in higher education. Also, English is recognised as the most important foreign language among others such as French, Russian, Chinese, and Japanese. Therefore, English is considered one of the important factors in the process of modernisation and industrialisation and that is why the Ministry of Education and Training of Vietnam (MoET) has determined that students in higher education have to take responsibility to surge national economic development by enhancing their professional knowledge and advancing their English language proficiency.

In 2008 the project "Teaching and learning foreign languages in the national education system, period 2008-2020" was set up by the MoET. Its main goal is by 2020 most of the Vietnamese youth and students will be able to use English fluently and confidently in order to turn foreign languages into one of the strengths of Vietnamese people, and contribute to the cause of modernisation and industrialisation of the country (Council of Europe, 2001). Accordingly, from 2011 all postgraduates of different disciplines who want to get a Master's Degree must achieve B1 level of English proficiency of the Common European Framework (CEF). For this reason, it is considered that designing new EFL courses based on the CEF is a need for tertiary institutions. 


\section{Statement of the Problem}

Researchers state that gaps between curriculum development and implementation usually exist. Once a curriculum is in place a number of important questions still need to be answered (Richards, 2001). Those questions are: "Is the curriculum achieving its goals?", "What is happening in the classroom?", "How is the curriculum being implemented?", and "Are administrators, teachers, and students satisfied with the curriculum?". Also, during the implementation of a curriculum or a programme, it is inevitable that challenges can arise, and the complexities of and incongruent relationship between curriculum policy, goals, and its practice are indicators of the implementation problems (Elmore \& Sykes, 1992).

The current B1 EFL course was first introduced in 2011 at the university where the current study was conducted. Accordingly, English is a compulsory subject for the Masters' Degrees of different disciplines, such as Civil Engineering, Environmental Technology, Information Technology, Business Administration and Electronic Engineering. A certificate of B1 English proficiency level is one of the requirements for graduation. The EFL course consists of 4 thirty-hour levels, so the total time for the course is 120 formal class hours. The course books used as the core materials are American English File-Book 2 and Book 3. However, since the course was instituted, there has been no formal feedback collected from the EFL teachers and the students about the effectiveness of the course. In addition, many students and teachers have complained that the students have not achieved their goals. That is why it is necessary to conduct a study to investigate how the course is implemented and verify whether the teachers' and students' assumptions are true.

\section{OBJECTIVES OF THE STUDY}

The main purpose of the current study was to investigate the effectiveness of the EFL course to seek implications for improvement and enhancement of English education for postgraduates at a Vietnamese tertiary institution. To meet the above overall purpose, the following specific objectives were the foci:

a. to investigate whether and how the students' language needs are analysed and learning objectives are initially formulated;

b. to investigate what the teachers' and students' perceptions about the time allocation, the content and materials and testing of the course are;

c. to investigate how much the teachers and students are satisfied with the whole course.

\section{RESEARCH QUESTIONS}

The current study aimed to find the answers to the following questions.

a. Are the students' language needs analysed and learning objectives initially formulated?

b. What are the teachers' and students' perceptions about the time allocation of the EFL curriculum?

c. What are the teachers' and students' perceptions about the content and materials of the course?

d. What are the teachers' and students' perceptions about testing?

e. To what extent are the students satisfied with the whole course?

\section{SigNificance OF THE STUdY}

This study is one of the very few studies conducted to investigate the effectiveness of the B1 EFL course at the tertiary level in HCMC, Vietnam. Therefore, the study is significant in several aspects. First, the study will bring practical values about the implementation of the B1 EFL course at the tertiary level in Vietnam. Second, the findings of the study will help course and material developers gain a better understanding of the EFL course implementation in higher educational system and of the challenges that EFL teachers are facing. Third, by means of identifying the strengths and weaknesses of the course, this study will help institutional managers make relevant changes to the EFL course to satisfy students' expectations. Finally, teachers are the main course implementers, and so the findings of the study will be helpful for them to make useful decisions, and to offer relevant changes to improve students' competencies and teachers' professional development. 


\section{METHODOLOGY}

\section{Participants}

The first group of participants was 53 students studying at postgraduate level from five departments. These students have already completed their four levels of English. The students participating in the survey vary in their sex, age and initial English proficiency level. Most of them, before taking the course, had a low proficiency level of English. The table below shows some major information about the students.

Table1. Information of Students $(N=53)$

\begin{tabular}{|c|c|c|c|c|c|}
\hline Gender & $N$ & Age & $N$ & English proficiency & $N$ \\
\hline \multirow[t]{2}{*}{ Male } & \multirow[t]{2}{*}{21} & $23-28$ & 23 & Pre-elementary & 3 \\
\hline & & $29-34$ & 21 & Elementary & 21 \\
\hline \multirow[t]{2}{*}{ Female } & \multirow[t]{2}{*}{32} & $35-40$ & 6 & Pre-intermediate & 18 \\
\hline & & 41-over & 3 & Intermediate & 11 \\
\hline
\end{tabular}

The second group of participants was 4 EFL teachers who taught English to the above students at postgraduate level at the university. The criterion for participant selection was the ease of access and availability. All the four EFL teachers are experienced teachers. They have been teaching English at the tertiary level for more than six years. The table below shows the information about the teachers.

Table2. Information of EFL Teachers $(N=4)$

\begin{tabular}{|c|c|c|c|c|c|}
\hline Gender & $N$ & Age & $N$ & Years of Teaching & $N$ \\
\hline \multirow[t]{2}{*}{ Male } & \multirow[t]{2}{*}{1} & $23-28$ & 0 & $1-5$ & 0 \\
\hline & & $29-34$ & 2 & $6-10$ & 2 \\
\hline \multirow[t]{2}{*}{ Female } & \multirow[t]{2}{*}{3} & $35-40$ & 1 & $11-15$ & 1 \\
\hline & & 41-over & 1 & 16-over & 1 \\
\hline
\end{tabular}

\section{Instruments and Procedures}

The first instrument employed to collect data of the current study was the survey questionnaire. To increase reliability and validity in the current study, a self-constructed questionnaire was developed and piloted on 8 students and 1 teacher. Then, the wordy or ambiguous items were revised. The final version of the questionnaire was used to gather data for the study. The questionnaire with five sections includes 26 items. The items of the first section for RQ1 were rated on two-point responses, i.e. Agree or Disagree, and the items of the last four sections for RQ2-5 were rated on four-point Likert items, i.e. Strongly agree (SA), Agree (A), Disagree (D), and Strongly disagree (SD). The second instrument was the Group interview carried out with 4 teachers. All the interview questions focused on the aspects investigated in the study regarding needs analysis, objectives, content and materials, and testing.

\section{RESUlTS AND DisCUSSION}

\section{Results of Research Question 1}

RQ1 attempted to find out whether the students' language needs and the curriculum objectives were initially identified. The findings are displayed in the table below.

Table3. Students' Perceptions about Needs Analysis and Objectives Formulation

\begin{tabular}{|l|l|l|l|}
\hline Items & $\mathbf{N}$ & \multicolumn{1}{|c|}{ Agree } & Disagree \\
\hline $\begin{array}{l}\text { 1. The students' language needs are analysed at the beginning of the } \\
\text { curriculum. }\end{array}$ & 53 & $11.3 \%$ & $88.7 \%$ \\
\hline $\begin{array}{l}\text { 2. The students are placed in the right class for their preliminary English } \\
\text { proficiency level. }\end{array}$ & 53 & $33.9 \%$ & $66.1 \%$ \\
\hline 3. Initially, the students are told about the objectives of the curriculum. & 53 & $94.3 \%$ & $5.7 \%$ \\
\hline 4. The objectives of the curriculum are clear and well-written. & 53 & $9.4 \%$ & $90.6 \%$ \\
\hline 5. The objectives of the curriculum meet the students' language needs. & 53 & $32.1 \%$ & $67.9 \%$ \\
\hline
\end{tabular}

Data displayed in Table 3 show that $88.7 \%$ of the students thought that their language needs were not analysed at the beginning of the course and $66.1 \%$ of them thought that they were not placed in the right class level for their preliminary English proficiency. Although nearly all the students $(94.3 \%)$ agreed that they were told about the objectives of the curriculum, $90.6 \%$ of them said that the 


\section{Le Van Tuyen}

objectives were not clear and feasible and $67 \%$ of them thought that the objectives did not meet their language needs.

Having similar perceptions of language needs analysis and objectives formulation, the four teachers revealed that students' language needs analysis was not conducted. For example:

T3 said, "We have taught some courses for some years. As we know, when the students enrol for the course, they do not take any placement test before they start the first course."

T4 said, "We do not know the students' proficiency level when we start teaching a class. When we start the first unit, we realise that many students in the class know little about English. They can not say anything in English."

Regarding the objectives of the course, all teachers said that the objectives were already formulated by someone else, and that they were asked to show the objectives to the students. However, they thought what was written in the objectives might not be based on what the students needed. In addition, three out of the four teachers did not think that the objectives could meet the students' language needs. For example:

$\mathrm{T} 1$ said "The objectives were already written, but they are not clear enough.

They sound very general. It is not easy for the students to achieve because they are less-able students."

These findings support many scholars' opinions about the importance of students' language needs analysis at the beginning of an EFL course. Scholars emphasise that knowing students' language needs, course designers or teachers will be able to identify the type of language areas and skills, and level of language proficiency the course should aim to deliver (Barbazette, 2006; Lessow-Hurley, 2003; Long, 2005; Nation \& Macalister, 2010; Richards \& Rodgers, 1986; Richards, 2001).

Therefore, needs analysis must be determined before decision about content and method can be made. Course designers should first identify a gap between what students are able to do and what they need to be able to do and consider what language students lack, want and what necessities are. Actually, the course designers did not know what the students needed when they took part in the EFL course. The data obtained from need analysis will help formulate general goals / aims and more specific objectives as intented outcomes, i.e., these specific objectives should realise students' needs and provide the basis for decision making in the course in terms of the content, instructional materials, teaching instruction and methods of assessment (Brinley, 1989).

\section{Results of Research Question 2}

RQ2 attempted to investigate both teachers' and students' perceptions about the time allocation for the course. The findings are displayed in the table below.

Table4. Students' Perceptions about the Time Allocation

\begin{tabular}{|l|l|l|l|l|l|}
\hline Items & N & SA & A & D & SD \\
\hline 1. There is adequate time for all learning activities. & 53 & $3.8 \%$ & $15.1 \%$ & $45.3 \%$ & $35.8 \%$ \\
\hline 2. The time allocated to the four skills are balanced. & 53 & $30.2 \%$ & $5.7 \%$ & $11.3 \%$ & $52.8 \%$ \\
\hline 3. The time allocated to each unit is adequate. & 53 & $11.3 \%$ & $3.8 \%$ & $17.0 \%$ & $67.9 \%$ \\
\hline $\begin{array}{l}\text { 4. The time allocated to each level is adequate for } \\
\text { achieving the objectives of the whole course. }\end{array}$ & 53 & $13.2 \%$ & $3.8 \%$ & $37.7 \%$ & $45.3 \%$ \\
\hline
\end{tabular}

The students' perceptions about the time allocation of the course are presented in table 4 . The findings showed that most of the students' did not think that the time allocation was sufficient for them to finish the course as expected. More specifically, $81.1 \%$ of the students thought that the time given to learning activities was insufficient; $64.1 \%$ of them thought that the time was not balanced for the four skills; $84.9 \%$ of them thought that the time allocated to each unit was insufficient; and $83 \%$ of them percieved that the time allocated to the whole course was insufficient for them to achieve the expected goals. Having similar perceptions of the time allocation, all the teachers thought that they could not complete their units satisfactorily due to time constraints. For example:

T2 said, "Many learning activities need time for pair work and group work. However, we have only 4 hours to comple one unit. Meanwhile, the syllabus requires us to cover almost every part of each unit." 
Lack of time may cause superficial teaching and learning, leading to a failure at achieving learning goals. Obviously, the course designers did not determine how long the course took in order that students could achieve the intended goals and objectives. Therefore, it was impossible for both teachers and students to implement the course effectively. According to the Council of Europe, in order to achieve B1 level of language proficiency, foreign language students need to study at least 400 formal class hours (Council of Europe, 2001).

\section{Results of Research Question 3}

Table5. Students' Perceptions about the Content and Materials

\begin{tabular}{|l|l|l|l|l|l|}
\hline Items & $\mathbf{N}$ & SA & A & D & SD \\
\hline $\begin{array}{l}\text { 1. The coursebook is relevant to the learning and } \\
\text { teaching context. }\end{array}$ & 53 & $26.4 \%$ & $49.1 \%$ & $20.7 \%$ & $3.8 \%$ \\
\hline $\begin{array}{l}\text { 2. The coursebook is used with the workbook during } \\
\text { the implementation of the course. }\end{array}$ & 53 & $22.6 \%$ & $1.9 \%$ & $39.7 \%$ & $35.8 \%$ \\
\hline $\begin{array}{l}\text { 3. The content integrates the four skills: listening, } \\
\text { speaking, reading and writing. }\end{array}$ & 53 & $35.8 \%$ & $37.7 \%$ & $24.6 \%$ & $1.9 \%$ \\
\hline $\begin{array}{l}\text { 4. The content is appropriate for the } \\
\text { students'preliminary English proficiency level. }\end{array}$ & 53 & $12.3 \%$ & $7.6 \%$ & $79.2 \%$ & $37.7 \%$ \\
\hline $\begin{array}{l}\text { 5. The coursebook provides a variety of tasks or } \\
\text { activities for learning and practicing. }\end{array}$ & 53 & $20.8 \%$ & $60.4 \%$ & $18.8 \%$ & $0 \%$ \\
\hline $\begin{array}{l}\text { 6. The topics, tasks and activities attract the students' } \\
\text { attention. }\end{array}$ & 53 & $18.7 \%$ & $3.8 \%$ & $21.0 \%$ & $56.5 \%$ \\
\hline $\begin{array}{l}\text { 7. Revision and consolidating tasks are provided for } \\
\text { the students after each unit. }\end{array}$ & 53 & $20.7 \%$ & $60.4 \%$ & $17.0 \%$ & $1.9 \%$ \\
\hline
\end{tabular}

Data relating to the students' perceptions about the content and materials of the course are shown in table 5. Regarding the context, $75.5 \%$ of the students thought that the course book was relevant to the context, i.e. for EFL students. The above perception was similar to all of the teachers' perceptions. They said that the course book was interesting and relevant to Vietnamese students. For example:

T3 said, "I think the course book is designed for EFL students, especially for non-English major students. It is a new course book and suitable for Vietnamese context."

Regarding the use of the workbook, $75.5 \%$ of them thought that they did not do any exercises in the workbook. It might be because the content of each unit was so long that they did not have time for other activities or exercises. Talking about this issue, two of the teachers said that because the content of each unit was rather long so they did not have time to correct the students' homework. For eaxmple:

T1 said, "After each unit, I ask my students to do assignments in the workbook. However, in class we do not have time for correction, so I'm not sure whether the students do the homework or not."

Regarding the skills covered in the course book, $73.5 \%$ of the students perceived that the course book covers all the four skills of English, which means during the class hours, the students had chance to practise the four skills. This perception was similar to all of the four teachers' perception. They said that the course book covered all the four English skills in different sections of each unit. However, data in table 5 shows that $79 . \%$ of the students were unable to follow the course book due to their low preliminary English proficiency level. It was obvious that those students faced a lot of difficulties in their learning. That is why, although $81.2 \%$ of them thought that a variety of tasks and activities are designed in the course book and $81.1 \%$ of them thought that after each unit they were provided consolidating tasks, most of them (77.5\%) thought that the tasks did not attract them very much. Regarding the above aspects, all of the teachers had similar perceptions to the students. For example:

T4 said, "I think that there are a variety of interesting tasks and activities for the students to practise, but many tasks may be too difficult for the students to learn, especially listening and writing tasks."

It was evident that less-able students could not follow the course book. It might be because the teacher did not redesign or simplify the tasks and activities to meet the students' level and interests, which might make them demotivate in learning. 


\section{Results of Research Question 4}

Table6. Students' Perceptions about Testing

\begin{tabular}{|l|l|l|l|l|l|}
\hline Items & $\mathrm{N}$ & $\mathrm{SA}$ & $\mathrm{A}$ & $\mathrm{D}$ & $\mathrm{SD}$ \\
\hline $\begin{array}{l}\text { 1. The end-of-term tests assess the students' English knowledge } \\
\text { areas such as vocabulary and grammar structures. }\end{array}$ & 53 & $0 \%$ & $1.9 \%$ & $37.8 \%$ & $60.3 \%$ \\
\hline $\begin{array}{l}\text { 2. The end-of-term tests assess the students' listening and } \\
\text { speaking skills. }\end{array}$ & 53 & $0 \%$ & $3.8 \%$ & $49.1 \%$ & $47.1 \%$ \\
\hline $\begin{array}{l}\text { 3. The end-of-term tests assess the students' reading and writing } \\
\text { skills. }\end{array}$ & 53 & $75.5 \%$ & $24.5 \%$ & $0 \%$ & $0 \%$ \\
\hline $\begin{array}{l}\text { 4. The content of the tests reflects what the students have learned } \\
\text { in the coursebook. }\end{array}$ & 53 & $0 \%$ & $25 \%$ & $56.6 \%$ & $18.4 \%$ \\
\hline 5. The students are satisfied with the ways they are tested. & 53 & $0 \%$ & $14.1 \%$ & $84.9 \%$ & $0 \%$ \\
\hline
\end{tabular}

Table 6 displays the data regarding the implementation of tesing of the course. Accordingly, $98.1 \%$ of the students revealed that their knowledge of English such as grammar and vocabulary is not tested. This result is similar to the teachers' perceptions and to the result of the test content analysis. All the teachers said that there were no sections designed to test the students' knowledge of grammar and vocabulary. Similarly, $96.2 \%$ of the students revealed that no tests of listening and speaking skills were implemented at the end of each level. More interestingly, all the teachers and $100 \%$ of the students revealed that both reading and writing skills were tested at the end of each level. For example:

T2 said, "I design the end-of-term test for my class. The test is based on a fixed format given in advanec. The test only covers reading and writing skills. Usually, 4 or 5 short passages and two writing tasks are designed in the test."

This result was also reflected by the result of the test content analysis. It was evident that the students' listening and speaking skills were not measured, leading to a failure at achieving the course goals. More dangerously, the teachers might not teach those skills in class; and consequently, the students may be unable to communicate in English. What is more, $75.0 \%$ of the students perceived that the content of the test was not designed based on what they had learned during each level. The teachers also confirmed this result. For example:

T3 said, "All the reading passages are extracted from different materials, not from the course book. However, the reading techniques which the students practise in class are used in the test."

It was evident that although reading passages were not extracted from the course book, reading techniques which were practised in class were also used in the test. Obviously, the reading test was designed in the right way.

Regarding item 5, $84.9 \%$ of the students revealed that they were not satisfied with the ways they were tested. In addition, all the teachers also raised their opinions that the four language skills should have been tested so that the students' competence could have been measured. For example:

T3 said, "I don't think the format of the end-of-term tests are suitable to and meet the course goals. What we want the students to learn is the four skills. However, only two skills are tested. In class, the students don't want to learn listening and speaking."

\section{Results of Research Question 5}

Table7. Students' Satisfaction with the Overal Course

\begin{tabular}{|l|l|l|l|l|l|}
\hline Item & N & SA & A & D & SD \\
\hline $\begin{array}{l}\text { 1. The students are satisfied with their knowledge of } \\
\text { vocabulary and grammar after the course. }\end{array}$ & 53 & $0 \%$ & $28.3 \%$ & $66.0 \%$ & $5.7 \%$ \\
\hline $\begin{array}{l}\text { 2. The students are satisfied with their English skills after } \\
\text { the course. }\end{array}$ & 53 & $0 \%$ & $32.0 \%$ & $56.6 \%$ & $11.4 \%$ \\
\hline $\begin{array}{l}\text { 3. The course motivates the students to learn English in } \\
\text { the future. }\end{array}$ & 53 & $16.9 \%$ & $47.2 \%$ & $35.9 \%$ & $0 \%$ \\
\hline $\begin{array}{l}\text { 4. The students are able to use English in their field of } \\
\text { work and study at intermediate level after the course. }\end{array}$ & 53 & $0 \%$ & $24.5 \%$ & $47.1 \%$ & $28.4 \%$ \\
\hline
\end{tabular}


The findings related to the students' satisfaction with the course are presented in table 7 .

Regarding knowledge of grammar and vocabulary, $71 . \%$ of the students were not satisfied with this aspect after the course; $68.0 \%$ of them were not satisfied with their English skills; and $75.5 \%$ of them revealed that they were unable to use English in their field of work and study. However, $64.1 \%$ of them thought that the course motivated them to learn English in the future for their lifelong study. Obviously, the whole course did not meet the goals formulated in advance in terms of knowledge and skills. It was evident that many aspects relating to the development and implementation of the course need to be revised and improved to meet the students' expectations.

\section{RECOMMENDATIONS}

The findings of the study provide both theoretical and practical implications for language curriculum designers and teachers in the process of development and implementation of an EFL course in the context of Vietnam.

First, the findings of the study suggest a need to analyse or assess students' language needs before starting an EFL course, especially for students like postgraduates who vary in age and English proficiency. Students should be grouped by proficiency levels in English classes.

Second, learning objectives must be specific and measurable, and can be reached to meet students' expects. In no way should they be formulated without being based on the students' language needs (Council of Europe, 2001), and impulsively determined by one or two people.

Third, when choosing a textbook for students in the Vietnamese context, it is essential for educators and teachers to make adaptation because English is considered as a foreign language in Vietnam and not all textbooks can be effectively applied in the Vietnamese context.

Fourth, in order to learn a foreign language, it takes time. Therefore, time allocation for each course must be carefully considered and determined. In order to achieve the level of B1 of English proficiency, it takes language students at least 400 formal class hours (Council of Europe, 2001).

Fifth, the CEF requires in-service training for teachers to understand and know how to refer to it in a specific context because the CEF is not a teaching methodology and it does not show teachers what to teach and how to teach (Council of Europe, 2001).

Finally, it is suggested that institutional policy makers and course designers should engage their teachers and students in redesigning the curriculum, redeveloping the teaching materials, and improving teaching methods and the testing system with reference to the CEF based on the goals of the course and students' entry proficiency levels.

\section{Conclusion}

This study was conducted in a university and in the middle stage of the Project 2020 "Teaching and learning foreign languages in the national education system, period 2008-2020" set up by the MoET of Vietnam. The results of the study have revealed that problems in the implementation of the EFL course for the postgraduates still exist. The study has provides an insight of how the teachers and students implement the course and what they are not satisfied with. Besides efforts that the managers and the teachers have made to enhance the quality of English language education for postgraduates, ineffective implementation in relation to language needs analysis, objective formulation, use of the course book and testing still exist. It is undoubted that many necessary things related to EFL course implementation at the university in specific and at the Vietnamese tertiary level in general need to be dealt with in the years to come. In addition, it is expected that this study will partly make a small contribution to the pool of knowledge about EFL course development and implementation.

\section{REFERENCES}

Bộ Giáo dục Đào tạo (2008). Quyết định 1400/QĐ-TTg về Dư án dạy và học ngoại ngũ trong hệ thốn giáo dục quốc gia giai đoạn 2008-2020. Trích từ trang Web Bộ GD-ĐT, Việt Nam.

Barbazette, J. (2006). Training needs assessment: Methods, tools, and techniques, Pfeiffer, California.

Brinley, G. (1989). The role of needs analysis in adult ESL programme. In R. John. (Ed.). The Second Language Curriculum, Cambridge University Press, Cambridge. 


\section{Le Van Tuyen}

Council of Europe (2001). Common Europe framework of reference for languages: Learning, teaching, assessment, Cambridge University Press, Cambridge.

Elmore, R., \& Sykes, G. (1992). Curriculum Policy. In P. Jackson (Ed.), Handbook of research on curriculum (pp. 185-215), Macmillan, New York.

Lessow-Hurley, J. (2003). Meeting the needs of second language learners, ASCD, Alexandria.

Long, M. H. ( 2005). Second language needs analysis, Cambridge University Press, Cambridge.

Nation, I.S.P. \& Macalister. J. (2010). Language curriculum design, Routledge, New York.

Richards, J \& Rodgers, T. (1986). Approaches and methods in language teaching, Cambridge University Press, Cambridge.

Richards, J. C. ( 2001). Curriculum development in language teaching, Cambridge Univerity Press, Cambridge.

\section{AUTHOR's BIOGRAPHY}

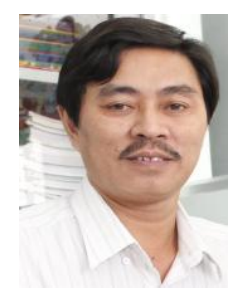

Le Van Tuyen, is a lecturer of English at Ho Chi Minh City University of Technology (HUTECH), Vietnam. His areas of interest include task-based language teaching, language learning assessments and curriculum evaluation. His research papers have been published in some international journals. 